\title{
Cartas à Paulo Freire: (des)esperança de professores(as) em tempos desinteressantes ${ }^{1}$
}

Carla Busato Zandavalli*, Lilian Andressa Oliveira Olegário**, Brenda Tavella Oliveira***

\section{Resumo}

O artigo retrata uma experiência pedagógica realizada no âmbito da disciplina de Teorias de Aprendizagem, em um Curso de Mestrado Profissional em Ensino de Ciências, de uma instituição pública federal de Mato Grosso do Sul. Foi solicitada aos pós-graduandos a escrita de uma carta respondendo a uma das três Cartas presentes na obra "Pedagogia da Indignação: Cartas pedagógicas e outros escritos", de Paulo Freire. A atividade objetivou analisar a situação atual de vida e formação dos professores, tomando como pressuposto a teoria freiriana, por meio do gênero textual preferido de Freire: as cartas. Participaram da atividade 18 mestrandos, a maioria professores convocados em redes públicas de ensino, que ministram disciplinas de Biologia, Química, Física e/ou atuam nos anos iniciais do ensino fundamental, como professores regentes. A análise das cartas foi feita por meio da análise categorial de Bardin (2016), observando-se a pré-análise, a exploração do material e o tratamento dos resultados, a inferência e a interpretação. Na exploração do material, primeiramente foi analisado o conjunto das informações, buscando-se categorias, unidades de registro e sua frequência e, na sequência, foram agrupadas em três grupos, tendo como referência a carta de Freire respondida pelos(as) mestrandos(as). Foram identificadas as seguintes categorias: Paulo Freire, Educação, Esperança, Desesperança/medo; Mudanças/transformações; Democracia/democratização; Consciência Humana; Professores/educadores; Alunos/ estudantes/crianças/ jovens; Riscos/perdas. Os diálogos dos(as) mestrandos(as) com o autor, por meio das cartas, denotaram a compreensão de aspectos centrais da Pedagogia e da Epistemologia de Freire. As cartas denotam o desenvolvimento mais acentuado da consciência crítica dos(as) mestrandos(as), mediante a análise da complexa realidade vivida por eles(as) e a compreensão e aplicação das categorias centrais da obra de Freire, o que permite concluir que os objetivos da atividade foram alcançados.

Palavras-chave: Formação Continuada de Professores. Ensino de Ciências. Mestrado Profissional. Paulo Freire.

* Professora da Faculdade de Educação e dos Programas de Mestrado em Educação/CPTL e de Ensino de Ciências, da UFMS. Campo Grande, MS, Brasil. carla.b.zandavalli@ufms.br

** Mestranda do Programa de Pós-graduação em Ensino de Ciências da UFMS. Campo Grande, MS, Brasil. lillianliz@ gmail.com

*** Mestranda do Programa de Pós-graduação em Ensino de Ciências da UFMS. Campo Grande, MS, Brasil. brendatavella@ hotmail.com

Recebido em: 01/08/2020; Aceito em: 01/03/2021

https://doi.org/10.5335/rbecm.v4i2.11523

http://creativecommons.org/licenses/by-nc-nd/4.0

ISSN: 2595-7376 


\section{Introdução}

Até bem pouco atrás

Poderíamos mudar o mundo Quem roubou nossa coragem?

Legião Urbana ${ }^{2}$

A motivação da escrita desse artigo nasceu de uma atividade desenvolvida no âmbito da disciplina de Teorias da Aprendizagem, no Mestrado de Ensino de Ciências, de uma instituição pública federal de Mato Grosso do Sul. Na referida disciplina são trabalhadas as teorias da aprendizagem relevantes para o ensino de ciências e, entre elas, a teoria de Paulo Freire, uma das mais utilizadas e reconhecidas na área (RICARDO, 2003; AULER; DELIZOICOV, 2006 ; GALIETA NASCIMENTO; VON LINSINGEN, 2006; SANTOS, 2007; AULER, 2013; ZAUITH; HAYASHI, 2013; LORENZETTI, 2018; LAYRARGUES, 2018).

Ao longo da disciplina foram estudadas as seguintes obras de Paulo Freire: Conscientização: teoria e prática da libertação: uma introdução ao pensamento de Paulo Freire (FREIRE, 1979), Educação e Mudança (FREIRE, 1984), Pedagogia do Oprimido (FREIRE, 1988), Pedagogia da Autonomia: saberes necessários à prática educativa (FREIRE, 1996), Pedagogia da Indignação: cartas pedagógicas e outros escritos (FREIRE, 2000).

$\mathrm{Na}$ atividade realizada em junho de 2019 foi solicitado aos(às) mestrandos(as) que, após a leitura das três cartas presentes na obra "Pedagogia da Indignação: Cartas pedagógicas e outros escritos", escolhessem uma carta e respondessem a Paulo Freire, tomando como lume a situação atual de vida e formação dos professores. Essa é a última obra de Paulo Freire publicada postumamente, a partir dos esforços de Ana Maria Araújo Freire, sua esposa, em reunir seus últimos escritos.

O objetivo da atividade foi o de analisar a situação atual de vida e formação dos professores, tomando como pressuposto a teoria freiriana e por meio do gênero textual preferido de Paulo Freire: as cartas.

Neste artigo buscou-se analisar as cartas elaboradas pelos(as) mestrandos(as), para identificar a percepção dos(as) mesmos(as) e a presença e importância das concepções, e categorias trazidas por Paulo Freire.

Participaram da atividade dezoito (18) mestrandos(as). Como se trata de Mestrado Profissional, a maioria são professores(as), atuando nas redes públicas municipal 
e/ou estadual dos Estados de Mato Grosso do Sul, Mato Grosso e São Paulo. Em razão do perfil do Curso, atuam nas disciplinas de Física, Química e Biologia nos anos finais do ensino fundamental e no ensino médio, bem como são professores dos anos iniciais do ensino fundamental.

A atividade suscitou discussões sobre a situação de des(esperança) que professores e professoras das redes pública e privada vivem no Brasil hoje, bem como a necessidade de refletir sobre a natureza das políticas públicas de formação inicial e continuada dos professores.

Este artigo, portanto, contempla, tanto o relato de uma experiência pedagógica, quanto a análise teórica das informações trazidas pelos estudantes-professores acerca das políticas educacionais atuais e das dificuldades crescentes que vêm enfrentando. A análise das cartas escritas à Paulo Freire foi realizada por meio da Análise de Conteúdo de Bardin (2016).

Foi realizada inicialmente a pré-análise, com a definição do material, ou seja, as 18 cartas escritas a Paulo Freire. Na leitura flutuante as cartas foram lidas inicialmente sem agrupamentos e depois, agrupadas, conforme a carta de Paulo Freire escolhida pelos(as) mestrandos(as). Não houve delimitação de amostra, foi tomado o conjunto das cartas, considerando-se que todas eram representativas do grupo de mestrandos(as), que também são professores(as) da educação básica. $\mathrm{Na}$ sequência foram formulados hipóteses e objetivos acerca da percepção dos(as) mestrandos(as) em relação às cartas de Freire, mas especialmente, à situação atual de vida e formação dos professores. Na exploração do material, foram identificadas, inicialmente, as categorias que emergiram do conjunto das cartas, suas unidades de registro e frequência e depois, na análise agrupada, foram tomadas as respostas a cada uma das três cartas. Mediante esse conjunto de informações foram feitas as inferências e a interpretação, observando-se a emergência das mesmas categorias e que coincidem com aspectos centrais da obra de Freire.

Nos itens a seguir são descritas as três cartas de Paulo Freire, seguidas da contextualização da situação de vida e de atuação dos(as) mestrandos(as), das respostas dadas pelos(as) mestrandos(as) à carta escolhida e respectivas análises.

\section{As cartas de Paulo Freire}

As três cartas de Paulo Freire tratam de situações concretas da vida cotidiana, discutidas a partir da ótica da democracia, da ideologia e da ação política dos cida- 
dãos(ãs). São cartas que tratam de esperança, da possibilidade de se fazer escolhas e do caráter ético das escolhas e ações, em uma linguagem dialógica.

Na primeira carta, em que explicita o espírito do livro, Paulo Freire manifesta sua vontade em escrever uma obra que pudesse interessar a pais, mães, filhos e filhas, professores e professoras, em uma escrita leve e que permitisse refletir acerca dos desafios das práticas docentes e das possibilidades de respostas aos mesmos.

Freire analisa as mudanças radicais ocorridas na sociedade e a distância cultural colocada para os membros de uma mesma família, frutos de tempos diferentes e transformações cada vez mais dinâmicas. Indica como essa distância é motor de conflitos, mas ao mesmo tempo de inovação e mudança. Salienta a importância de homens e mulheres assumirem o risco do novo, entenderem os processos de mudanças e as possibilidades de diversidade de escolhas no campo da política, dos costumes, do gosto estético, das artes, da moral, da sexualidade, da linguagem, das estruturas de poder da sociedade, tendo clareza que tais mudanças são refreadas pelas forças retrógadas que atuam no meio social. Defende a necessidade de que a presença das pessoas no mundo não seja neutra, nem de mera adaptação, mas marcada por escolhas e criticidade, como também por limites, necessários às práticas sociais e democráticas:

[...]. É porque podemos transformar o mundo, que estamos com ele e com outros. Não teríamos ultrapassado o nível de pura adaptação ao mundo se não tivéssemos alcançado a possibilidade de, pensando na própria adaptação, nos servir dela para programar a transformação. É por isso que uma educação progressista jamais pode em casa ou na escola, em nome da ordem e da disciplina, castrar a altivez do educando, sua capacidade de opor-se e impor-lhe um quietismo negador do seu ser. É por isso que devo trabalhar a unidade entre meu discurso, minha ação e a utopia que me move. É neste sentido que devo aproveitar toda oportunidade para testemunhar o meu compromisso com a realização de um mundo melhor, mais justo, menos feio, mais substantivamente democrático. É neste sentido também que é importante sublinhar à criança que, zangada, não importa por que, esperneia e agride quem dela se aproxima, com ponta-pés, há limites reguladores de nossa vontade quanto estimular a necessidade de autonomia ou de auto-afirmação a uma criança tímida ou inibida. É preciso inclusive, deixar claro, em discursos lúcidos e em práticas democráticas, que a vontade só se autentica na ação de sujeitos que assumem seus limites. A vontade ilimitada é a vontade despótica, negadora de outras vontades e, rigorosamente, de si mesma. É a vontade ilícita dos "donos do mundo" que, egoístas e arbitrários, só se vêem a si mesmos. (FREIRE, 2000, p. 33-34, grifos do autor).

Freire fala da relação dialética entre liberdade e autoridade, na qual se estabelece "[...] uma autoridade ciosa de seus limites em relação com uma liberdade zelosa igualmente de seus limites e de suas possibilidades”. (FREIRE, 2000, p. 35). 
O autor dirige essa reflexão apontando a "tirania da liberdade" a qual algumas famílias se submetem ao não oferecer limites mínimos aos seus filhos. Em tempos desinteressantes, essa reflexão pode ser extrapolada também à liberdade ilimitada com que algumas esferas do poder político e econômico trabalham, blindadas pelo apoio de parcela da população, agindo "em nome do povo", mas em torno de decisões, escolhas e palpites meramente pessoais, sem sustentação da legislação vigente e, especialmente, dos preceitos constitucionais.

Freire trata, ainda, da importância da educação na medida em que os sujeitos percebem o mundo e a realidade humana como construções humanas mutáveis e se percebem enquanto sujeitos aptos a operarem tais mudanças, a defenderem projetos, sonhos e utopias.

Destaca a carga ideológica dos discursos fatalistas que sustentam a impossibilidade das mudanças, advinda dos interesses para a manutenção do existente, mesmo que injusto e desigual, ou da acomodação de quem fraqueja movido pela desesperança e diferencia essas origens:

Mas, é importante enfatizar que há uma diferença fundamental entre quem se
acomoda perdidamente desesperançado, submetido de tal maneira à asfixia da
necessidade, que inviabiliza a aventura da liberdade e a luta por ela, e quem tem,
no discurso da acomodação, um instrumento eficaz de sua luta - a de obstaculizar a
mudança. O primeiro é o oprimido sem horizonte; o segundo, o opressor impenitente.
Esta é uma das razões por que o alfabetizador progressista não pode contentar-se
com o ensino da leitura e da escrita que dê as costas desdenhosamente à leitura do
mundo. (FREIRE, 2000, p. 41).

O autor acentua, ainda, a importância, em uma prática pedagógica progressista, que o(a) educador(a) ensine rigorosamente os conteúdos, mas desafie o(a) estudante "[...] a pensar criticamente a realidade social, política e histórica em que é uma presença”. (FREIRE, 2000, p. 44). Da mesma forma, reclama a necessidade de haver coerência entre a ação do(a) educador(a) e seu discurso ou proposições.

Observa que a mudança requer coragem, rebeldia, vontade e esperança em relação ao futuro, pois sem esperança não se vence os limites postos pelo outro ou por nós mesmos. $\mathrm{Na}$ esteira da esperança retoma os objetivos das cartas, os de desafiar pais, mães, professores, professoras, operários e estudantes a refletirem sobre o papel que cabe a cada um na construção e aperfeiçoamento da democracia entre nós (FREIRE, 2000). 
Discute a necessidade de superar a democracia formal, que aceita e alimenta desigualdades ou a democracia fundada na ética do mercado, movida pelo lucro e não pela ética.

Na segunda carta intitulada "Do direito e do dever de mudar o mundo", Freire (2000) reafirma a importância de que todos tenham clareza da possibilidade da mudança e das dificuldades em operá-las em face aos condicionantes sociais, políticos e econômicos. Trata essa relação dialética como "sonhos e contra sonhos".

Salienta que a opção por um posicionamento progressista deve se manifestar, com coerência, em qualquer função ou lugar, na defesa indefectível ao respeito ao(à) outro(a) e à sua dignidade, à sua possibilidade de ser no mundo. $\mathrm{O}$ que significa recusar posições fatalistas que auferem poderes determinantes a um ou outro condicionante (social, político, econômico, religioso...), sem negar a sua existência. Nas palavras do autor:

\begin{abstract}
Se as estruturas econômicas, na verdade, me dominam de maneira tão senhorial, se, moldando meu pensar, me fazem objeto dócil de sua força, como explicar a luta política, mas, sobretudo, como fazê-la e em nome de quê? Para mim, em nome da ética, obviamente, não a ética do mercado, mas da ética universal do ser humano, para mim, em nome da necessária transformação da sociedade de que decorra a superação das injustiças desumanizantes. E tudo isso porque, condicionado pelas estruturas econômicas, não sou, porém, por elas determinado. Se não é possível desconhecer, de um lado, que é nas condições materiais da sociedade que se gestam a luta e as transformações políticas, não é possível, de outro, negar a importância fundamental da subjetividade na história. [...] Para mim, não é possível falar de subjetividade a não ser se compreendida em sua dialética relação com a objetividade. [...]. (FREIRE, 2000, p. 57).
\end{abstract}

Afirma que a subjetividade só pode ser efetivamente compreendida em sua relação dialética com a objetividade, a partir de uma concepção não mecanicista de história, seja de direita ou de esquerda. Considera que apenas nessa percepção se expressa efetivamente a importância da educação, a ser vivida como prática educativa radical, estimuladora da curiosidade crítica, da busca pela razão de ser dos fatos. Afirma ainda, que a capacidade de pensar, refletir, indagar, duvidar... deve ser um direito assegurado às crianças, bem como a o direito de aprender a decidir com ações concretas.

Exemplifica a experiência do movimento dos Sem-Terra no Brasil, como expressão viva da crença no poder das utopias e da transformação. E manifesta como seria positivo se outras categorias excluídas socialmente também se organizassem e marchassem em busca de efetiva igualdade, por ser "A marcha esperançosa dos que sabem que mudar é possivel" (FREIRE, 2000, p. 61). 
Na terceira carta "Do assassinato de Galdino Jesus dos Santos - índio pataxó", que ficou inconclusa, Freire analisa a coisificação das pessoas e a soberania do valor de mercado, a partir do assassinato cruel do índio pataxó que dormia num terminal de ônibus em Brasília, realizado por adolescentes de classe média. Procura refletir acerca dos lugares de vida e educação desses jovens e da brutalidade de sua escolha em "brincar de matar gente" e retoma as ideias da primeira carta na qual trata do risco da ausência do limite social, o uso indiscriminado de uma liberdade sem responsabilidade dada a filhos de certas camadas socioeconômicas. Analisa a construção de valores desses jovens com base na ética do mercado, na qual a vida de alguém vale pelo que se ganha no mês e destaca a urgência em se lutar por princípios de uma ética universal que valorize a vida de seres humanos, animais, plantas.

A conclusão do texto inconcluso é essencial e, dada a sua atualidade, vale citá-la:

Não é possível refazer este país, democratizá-lo, torná-lo sério, com adolescentes brincando de matar gente, ofendendo a vida, destruindo o sonho, inviabilizando o amor. Se a educação sozinha não transforma a sociedade, sem ela tampouco a sociedade muda.

Se a nossa opção é progressista, se estamos a favor da vida e não da morte, da equidade e não da injustiça, do direito e não do arbítrio, da convivência com o diferente e não de sua negação, não temos outro caminho senão viver plenamente a nossa opção. Encarná-la, diminuindo assim a distância entre o que fizemos e o que fazemos.

Desrespeitando os fracos, enganando os incautos, ofendendo a vida, explorando os outros, discriminado o índio, o negro, a mulher não estarei ajudando meus filhos a ser sérios, justos e amorosos da vida e dos outros... (FREIRE, 2000, p. 67).

As cartas, escritas em 1997 e complementadas por Ana Maria, que contextualiza esses momentos, fazem menções a situações desse momento histórico, mas continuam cada vez mais necessárias, pois parecem antecipar reflexões úteis aos momentos intranquilos dos anos 2000 .

\section{contexto gerador das respostas}

Para analisar o teor das cartas e as reflexões trazidas pelos(as) mestrandos(as), antes é essencial compreender quem são e de qual lugar falam.

Os(as) mestrandos(as) são predominantemente do sexo feminino $(77,7 \%)$ e jovens, já que 77,7 \% se encontram nas faixas etárias de 20 a 36 anos (Tabela 1), idade média de 30,6 anos e moda 25 anos. 
Tabela 1: Faixas etárias dos(as) mestrandos(as) participantes do estudo

\begin{tabular}{l|r|r|r|r|r|r}
\hline Faixas etárias & 20 a 25 anos & 26 a 30 anos & 31 a 36 anos & 37 a 40 anos & 41 a 45 anos & Total \\
\hline Quantidade & 5 & 6 & 3 & 1 & 3 & 18 \\
\hline$\%$ & 27,7 & 33,3 & 16,7 & 5,6 & 16,7 & 100 \\
\hline
\end{tabular}

Fonte: Dados da pesquisa.

A maioria dos participantes é da cor/raça branca (77,7\%), seguida da parda $(16,7 \%)$ e da indígena (5,6\%). Essa distribuição difere um pouco da distribuição da população brasileira, dados do último Censo (Tabela 2) e da distribuição de professores no Brasil (Tabela 3), mas não da composição no ensino superior brasileiro, que continua sendo majoritariamente branca.

Tabela 2: Distribuição da população brasileira segundo declaração de raça/cor - Brasil - 2010

\begin{tabular}{c|c|c|c|c|c|c|c|c|c|c|c|c|c}
\hline \multirow{2}{*}{ Ano } & \multirow{2}{*}{ Total } & \multicolumn{2}{|c|}{ Branca } & \multicolumn{2}{c|}{ Preta } & \multicolumn{2}{c|}{ Parda } & \multicolumn{2}{c|}{ Amarela } & \multicolumn{3}{|c|}{ Indígena } & \multicolumn{2}{c}{ Não Declarada } \\
\cline { 3 - 13 } & & $\mathrm{N}$ & $\%$ & $\mathrm{~N}$ & $\%$ & $\mathrm{~N}$ & $\%$ & $\mathrm{~N}$ & $\%$ & $\mathrm{~N}$ & $\%$ & $\mathrm{~N}$ & $\%$ \\
\hline 2010 & 190.755 .799 & 91.051 .646 & 47,7 & 14.517 .961 & 7,6 & 82.277 .333 & 43,1 & 2.084 .288 & 1,1 & 817.963 & 0,4 & 6.608 & 0,003 \\
\hline
\end{tabular}

Fonte: INSTITUTO BRASILEIRO DE GEOGRAFIA E ESTATÍSTICA. Censo Demográfico, 2010.

Tabela 3: Professores por raça/cor e etapa de ensino - Brasil - 2009/2013/2017

\begin{tabular}{|c|c|c|c|c|c|c|c|c|c|c|c|c|c|}
\hline \multirow{2}{*}{ Ano } & \multirow{2}{*}{ Total } & \multicolumn{2}{|c|}{ Branca } & \multicolumn{2}{|c|}{ Preta } & \multicolumn{2}{|c|}{ Parda } & \multicolumn{2}{|c|}{ Amarela } & \multicolumn{2}{|c|}{ Indígena } & \multicolumn{2}{|c|}{ Não declarada } \\
\hline & & $\mathrm{N}$ & $\%$ & $\mathrm{~N}$ & $\%$ & $\mathrm{~N}$ & $\%$ & $\mathrm{~N}$ & $\%$ & $\mathrm{~N}$ & $\%$ & $\mathrm{~N}$ & $\%$ \\
\hline 009 & 857.2 & 712.089 & 38,3 & 54.248 & 2,9 & 5.967 & 19,7 & 10.374 & 0,6 & 6.926 & 0,4 & 707.674 & 38,1 \\
\hline 2013 & 017.0 & 862.151 & 42,7 & 78.104 & 3,9 & 487.641 & 24,2 & 11.482 & 0,6 & 10.114 & 0,5 & 567.579 & 28,1 \\
\hline 2017 & 2.078 .910 & 872.435 & 42,0 & 84.934 & 4,1 & 524.078 & 25,2 & 14.352 & 0,7 & 12.738 & 0,6 & 570.373 & 27,4 \\
\hline
\end{tabular}

Fonte: Carvalho (2018, p. 22).

Franco e Cunha (2015), ao analisarem o perfil dos estudantes das Instituições Federais de Educação Superior (IFES), apontam para um decréscimo gradativo da raça/cor branca, no período de 2004 a 2014, e o crescimento dos pardos e pretos, o que demonstra o avanço propiciado pela política de cotas, embora ainda os estudantes das IFES sejam majoritariamente brancos $(45,67 \%)$.

Tabela 4: Distribuição dos graduandos segundo cor ou raça em 2004, 2010 e 2014 (Em \%)

\begin{tabular}{l|c|c|c}
\hline \multicolumn{1}{c|}{ Cor ou raça } & Graduandos Ifes (2004) & Graduandos Ifes (2010) & ${\text { Graduandos Ifes }(2014)^{2}}^{1}$ \\
\hline Sem declaração & 0,00 & 0,00 & 3,78 \\
Amarela & 4,50 & 3,06 & 2,34 \\
Branca & 59,40 & 53,93 & 45,67 \\
Parda & 28,30 & 32,08 & 37,75 \\
Pretos & 5,90 & 8,72 & 9,82 \\
Indígenas & 2,00 & 0,93 & 0,64 \\
\hline
\end{tabular}

Fonte: Franco e Cunha (2015) a partir de dados do Fonaprace (2004, 2010); Cepes (2014).

Notas: ${ }^{1}$ Pesquisas Fonaprace 2004 e 2010. ${ }^{2}$ Cálculos dos autores, com base nos microdados do Cepes (2014). 
Quanto à formação dos participantes do estudo, a maioria $(72,2 \%)$ possui Licenciatura em Ciências Biológicas ou Biologia; 11,1\% Licenciatura em Química, 11,1\% Pedagogia, 5,6\% Bacharelado e Licenciatura em Ciências Biológicas. Entre os participantes, $100 \%$ não cursaram outro Curso de Pós-Graduação Stricto Sensu.

Os(as) mestrandos(as) residem e atuam, predominantemente (89\%), em Mato Grosso do Sul, sendo 72\% em Campo Grande, a capital do Estado e local em que é ofertado o curso, 5,6\% em Miranda, 5,6\% em Bela Vista e 5,6\% em Coxim. Municípios de áreas diferentes no estado. Há dois mestrandos(as) de estados vizinhos, sendo 5,6\% do Estado de São Paulo, município de Pindamonhangaba e 5,6\% do Estado de Mato Grosso, município de Campo Verde. Vale destacar que há uma aluna de etnia indígena, moradora de uma aldeia em Miranda, que é professora da escola da aldeia e a primeira indígena formada em Biologia em Mato Grosso do Sul.

Em relação à atuação profissional, 88,8\% são professores(as), 5,6\% professor(a) e técnico(a) em laboratório; 5,6\% apenas técnico(a) em laboratório. Entre os docentes 66,6\% são professores(as) de Ciências Biológicas e Biologia; 11,1\% professores(as) de Química; 11,1\% professores dos anos iniciais do Ensino Fundamental e 5,6\% atuam como técnico(a) na Secretária de Estado de Educação do Mato Grosso do Sul.

Quanto à rede de ensino, 55,6\% dos professores atuam na rede Estadual, 33,3\% na rede municipal, $16,7 \%$ na rede privada ${ }^{3}$, observando-se que $16,7 \%$ atuam em mais de uma rede de ensino.

Sobre a liberação do trabalho para licença de estudos, 72,2\% não tiveram qualquer tipo de liberação, 27,8\% tiveram liberação parcial. Ou seja, 100\% não tiveram liberação total. Outro fator a se destacar é que os cursos de mestrado profissional não contam com bolsas por parte do CNPq.

Com relação ao regime de trabalho, $16,7 \%$ são concursados(as) e 83,3\% convocados ou contratados, percentual bastante superior à média nacional indicada por Carvalho (2018), que aponta para o ingresso de mais de 50\% dos professores por meio concurso público nas redes públicas de ensino.

Esse dado mostra a piora das condições de trabalho dos professores em Mato Grosso do Sul, pois as convocações não garantem direitos trabalhistas, sendo os professores convocados em janeiro ou fevereiro, na rede municipal de Campo Grande são demitidos no período das férias, portanto, deixam de receber salários ao longo do ano. Em alguns governos as férias são pagas parceladamente ao longo dos contratos, mas há variações. Gatti (apud CARVALHO, 2018, p. 52), ratifica essa percepção: 
A grande quantidade de vínculos temporários, com ligeira tendência de crescimento, demonstra, na verdade, uma distorção no sistema de ensino, pois expressa a precarização do vínculo de trabalho para esses profissionais. Eles têm as mesmas responsabilidades dos profissionais concursados, mas com salários menores e sem direito a formações continuadas e outros benefícios da carreira de docentes[...].

No momento em que foi feita a coleta de informações, em 2019, os(as) mestran$\operatorname{dos}($ as) docentes estavam atuando 40 horas ou mais e buscando meios alternativos para a participação nas aulas do mestrado, dadas as dificuldades em compatibilizar trabalho e formação continuada.

Os dados dos(as) mestrandos(as) com atuação docente corroboram, em boa parte, o perfil do professor da educação básica no Brasil, elaborado por Carvalho (2018) no âmbito do IPEA, com dados extraídos do Censo da Educação Básica dos anos 2009, 2013 e 2017, analisando características demográficas, do contexto de trabalho e da formação do docente:

O estudo demonstrou que os professores típicos brasileiros em 2017 são mulheres ( $81 \%$ ), de raça/cor branca ( $42 \%$ ) ou parda (25,2\%), com idade média de 41 anos, alocadas, prioritariamente, nas etapas iniciais da educação básica. Uma minoria declarou ser portadora de necessidades especiais (0,31\% em 2017). A escolaridade do professor é predominantemente de nível superior em todas as etapas de ensino - sendo que a maior parte é em licenciatura. Dos graduados, 36\% são portadores de títulos de pós-graduação lato ou stricto sensu. A maior parte dos professores é concursada e leciona em apenas uma escola, 38\% em uma única turma e $40 \%$ ministra uma única disciplina. (CARVALHO, 2018, p. 5).

Os aspectos divergentes ficam por conta da média de idade, que é menor entre os participantes do estudo, bem como o fato da maioria ser convocada e atuar em mais de uma escola.

As condições de trabalho nas redes públicas de Mato Grosso do Sul vêm piorando gradativamente nos últimos anos, observando-se em 2019, ações que trouxeram maior instabilidade aos docentes.

Em 10 de julho de 2019, o governo do estado de Mato Grosso do Sul, sancionou a Lei Complementar $n^{\circ} 266$, que altera, acrescenta e revoga dispositivos à Lei Complementar no 87, de 31 de janeiro de 2000, que dispõe sobre o Estatuto dos Profissionais da Educação Básica do Estado de Mato Grosso do Sul. Entre as principais alterações, a Lei previu que os processos de convocação de professores, obedeçam à classificação de um Banco de Reserva de Profissionais para a Função Docente temporária, sendo esse banco constituído por meio de processo seletivo 
simplificado, regido por edital específico, abrangendo prova objetiva, de caráter eliminatório, versando sobre conhecimentos gerais e pedagógicos; e análise curricular, de caráter classificatório, a qual será realizada por intermédio de pontuação de títulos, conforme estabelecido em regulamento próprio.

Outra mudança refere-se à ampliação do prazo da convocação do profissional para 1 (um) ano, admitida a prorrogação, não ultrapassando 2 (dois) anos, pois após esse período o candidato deve submeter-se novamente a processo seletivo. Mas a mudança mais significativa foi relativa à diminuição/o da remuneração dos convocados em cerca de $30 \%$, permitida a partir do artigo 17-B:

Art. 17-B. A remuneração a ser paga ao profissional convocado para 40 (quarenta) horas semanais será estabelecida em tabela própria a ser fixada em regulamento observadas as seguintes condicionantes:

I - o valor da remuneração não será inferior ao Piso Nacional;

II - a remuneração será prevista de forma escalonada, de acordo com o grau de qualificação do profissional convocado;

III - não se aplicará aos profissionais convocados a tabela remuneratória vigente para os Profissionais da Educação Básica.

Parágrafo único. Na hipótese de a convocação ser inferior a 40 (quarenta) horas semanais, o valor da remuneração será calculado proporcionalmente. (NR). (MATO GROSSO DO SUL, 2019, p. 2, grifo nosso).

$\mathrm{Na}$ rede municipal de ensino de Campo Grande as licenças para estudo aos profissionais da educação passaram a ser negadas a partir de 2019, sendo proibido aos Diretores das Escolas afastamento da escola para atividades que não sejam coordenadas pela Secretaria Municipal de Educação de Campo Grande (SEMED). Outro fato complicador foi o fechamento de laboratórios de ciências na maioria das escolas, sendo mantidos apenas os situados em escolas de tempo integral.

Esse cenário de instabilidade local, nas redes municipal e estadual, se soma às dificuldades observadas no âmbito federal, em significativa piora a partir de 2019. Um quadro que traz maior angústia aos docentes, especialmente aos convocados, que precisam buscar, a cada semestre, ou mesmo antes do seu fim, a tentativa de manutenção e/ou ampliação da carga horária de trabalho. Essa instabilidade também gera fraturas importantes na mobilização sindical e na possibilidade de reivindicações da categoria docente.

Parte desses aspectos aparecem nas respostas às cartas a Paulo Freire, descritas a seguir. 


\section{As respostas à Paulo Freire}

As cartas dos mestrandos, escritas em 2019, ou seja, 22 anos após a escrita de Paulo Freire, atenderam à solicitação da atividade, pois são efetivamente cartas, trazem uma linguagem dialógica, de conversa entre sujeitos históricos e sociais.

Elas estão marcadas pela denúncia da situação difícil que a educação e os educadores estão passando, pelo reconhecimento da importância das ideias do autor para a educação e a sociedade brasileira e pela incredulidade acerca das críticas recentes à sua obra. Outro aspecto presente em muitas cartas é a esperança que os escritos trazem aos educadores em momentos difíceis.

$\mathrm{Na}$ Tabela 5 são expostas as categorias, unidades de registro e frequências ${ }^{4}$ (BARDIN, 2016) das informações obtidas no conjunto das cartas, para analisar aspectos mais globais. Entre as categorias foram identificadas: Paulo Freire, Educação, Esperança, Desesperança/medo; Mudanças/transformações; Democracia/ democratização; Consciência Humana; Professores/educadores; Alunos/ estudantes/ crianças/ jovens; Riscos/perdas.

Tabela 5: Categorias, unidades de registro e frequências das cartas à Paulo Freire

(continua...)

\begin{tabular}{|c|c|c|}
\hline Categorias & Unidades de registro & Frequência \\
\hline \multirow{9}{*}{$\begin{array}{l}\text { Paulo Freire/ } \\
\text { Freire/ } \\
\text { Paulo }\end{array}$} & Mudanças; mudar o mundo & 15 \\
\hline & Exemplo; referência; admiração; legado & 8 \\
\hline & Contribuições; incentivos & 7 \\
\hline & Humildade; ponderação; sabedoria; autenticidade; solidariedade & 6 \\
\hline & 然, & 5 \\
\hline & Esperança; sonho & 5 \\
\hline & Método & 5 \\
\hline & Coragem; recusa ao fatalismo & 3 \\
\hline & Luta pela democratização de ensino & 1 \\
\hline Subtotal & & 55 \\
\hline \multirow{7}{*}{ Educação } & Escolas; salas de aula & 8 \\
\hline & $\begin{array}{l}\text { Educação crítica; ação progressista; educação transformadora; radical; questionadora; } \\
\text { estimulante }\end{array}$ & 6 \\
\hline & Superação das injustiças; futuro do país; cidadania; & 3 \\
\hline & Conceitos; conteúdos & 3 \\
\hline & Sonho; sonho embasado historicamente & 3 \\
\hline & Autonomia humana; capacidade de pensar, conjecturar, decidir, projetar, sonhar & 2 \\
\hline & Passa seu pior momento; atacada a todo instante & 2 \\
\hline \multicolumn{2}{|l|}{ Subtotal } & 27 \\
\hline \multirow{3}{*}{ Esperança } & Esperança nas mudanças & 2 \\
\hline & Educação vale a pena & 1 \\
\hline & Contra-sonhos & 1 \\
\hline Subtotal & & 4 \\
\hline
\end{tabular}




\begin{tabular}{|c|c|c|}
\hline \multirow{7}{*}{$\begin{array}{l}\text { Desesperança/ } \\
\text { Medo }\end{array}$} & Momentos tenebrosos; tempos sombrios; tempos difíceis; tempos nebulosos & 5 \\
\hline & O século XXI assombra, traz medos e incertezas; época turbulenta, de extremos & 2 \\
\hline & Desânimo & 1 \\
\hline & Negligência & 1 \\
\hline & Falta de esperança & 1 \\
\hline & Incertezas do rumo educacional do país & 1 \\
\hline & A opressão ainda impera no nosso país & 1 \\
\hline \multicolumn{2}{|l|}{ Subtotal } & 12 \\
\hline \multirow{7}{*}{$\begin{array}{l}\text { Mudanças/ } \\
\text { Transformações }\end{array}$} & Lutas intensificadas; lutas pelos direitos; lutas pela democracia & 16 \\
\hline & Sonhos; projetos & 4 \\
\hline & Brasil & 4 \\
\hline & Justiça; igualdade & 2 \\
\hline & Utopia & 1 \\
\hline & Desafios & 1 \\
\hline & Autenticidade & 1 \\
\hline \multicolumn{2}{|l|}{ Subtotal } & 29 \\
\hline \multirow{7}{*}{$\begin{array}{l}\text { Democracial } \\
\text { Democratização }\end{array}$} & Liberdade; escolha e decisão & 2 \\
\hline & Movimentos sociais & 1 \\
\hline & Minorias & 1 \\
\hline & Resistência às desigualdades & 1 \\
\hline & Responsabilidade humana coletiva & 1 \\
\hline & Eticidade & 1 \\
\hline & Educação igualitária & 1 \\
\hline \multicolumn{2}{|l|}{ Subtotal } & 8 \\
\hline \multirow{6}{*}{$\begin{array}{l}\text { Consciência } \\
\text { humana }\end{array}$} & Reflexão/refletir & 4 \\
\hline & Criticidade/consciência crítica; avaliação crítica do ambiente em que está inserido & 3 \\
\hline & Consciência da incompletude & 1 \\
\hline & Ideias & 1 \\
\hline & Consciência de classe & 1 \\
\hline & Oprimido & 1 \\
\hline \multicolumn{2}{|l|}{ Subtotal } & 11 \\
\hline \multirow{5}{*}{$\begin{array}{l}\text { Professores(as)/ } \\
\text { Educadores(as) }\end{array}$} & $\begin{array}{l}\text { Comprometidos com a educação, mundo, realidade, justiça; não podem ser meros } \\
\text { transmissores de conteúdos programáticos }\end{array}$ & 3 \\
\hline & Exilados dentro do nosso país; exilados dentro das cercas ideológicas violentas & 2 \\
\hline & Desesperançados; acomodados; oprimidos & 2 \\
\hline & "Doutrinadores" & 1 \\
\hline & Retirar as vendas colocadas nos alunos & 1 \\
\hline \multicolumn{2}{|l|}{ Subtotal } & 9 \\
\hline \multirow{6}{*}{$\begin{array}{l}\text { Aluno/estudante/ } \\
\text { Crianças/jovens }\end{array}$} & $\begin{array}{l}\text { Devem ser estimulados pelos professores a pensar criticamente e superar a postura } \\
\text { fatalista; requerem uma formação que estimule }\end{array}$ & 3 \\
\hline & $\begin{array}{l}\text { Não possuem consciência de classe; "objetos" dentro da sociedade; falta de coragem } \\
\text { dada pela situação econômica e social }\end{array}$ & 3 \\
\hline & Vivência democrática; ainda têm sede de mudanças & 2 \\
\hline & Tirania da liberdade; dar amor é dar limites & 2 \\
\hline & Devem ter direito à educação & 1 \\
\hline & Individualistas e competitivos & 1 \\
\hline \multicolumn{2}{|l|}{ Subtotal } & 12 \\
\hline \multirow{5}{*}{ Riscos/perdas } & $\begin{array}{l}\text { Guerra ideológica; polarização; intensificação da alienação; ridicularização da consci- } \\
\text { ência crítica }\end{array}$ & 5 \\
\hline & $\begin{array}{l}\text { Retirada de direitos; enfraquecimento da luta social; perdas de conquistas de movi- } \\
\text { mentos sociais }\end{array}$ & 3 \\
\hline & Perda de vidas; perdas da democracia; perda da liberdade de expressão & 3 \\
\hline & Elite maximizadora de injustiças & 1 \\
\hline & Escola sem partido & 1 \\
\hline \multicolumn{2}{|l|}{ Subtotal } & 13 \\
\hline \multicolumn{2}{|l|}{ Total geral } & 180 \\
\hline
\end{tabular}

Fonte: Cartas a Paulo Freire

Nota: Tabela elaborada pelos autores 
As unidades de registro vinculadas à categoria "Paulo Freire" são todas de caráter positivo e podem ser agrupadas em três núcleos: a) transformação - A capacidade de mudar o mundo; a esperança, o sonho; coragem; a recusa ao fatalismo; reflexão; b) exemplo de vida e referência - Exemplo; referência; admiração; legado; Contribuições; incentivos; Humildade; ponderação; sabedoria; autenticidade; solidariedade; c) dimensão pedagógica - Método; Luta pela democratização de ensino.

A categoria "Educação", aparece diretamente relacionada à educação formal, ao ensino, algo compreensível dado o perfil dos(as) mestrandos(as), predominantemente professores(as) de educação básica. A caracterização desejada para essa educação está vinculada à função social da educação/escola, vista como "futuro do país", meio de superação das injustiças e constituição da cidadania, meio para o desenvolvimento da autonomia humana e das capacidades de pensar, conjecturar, decidir, projetar, sonhar. Almejam, assim, uma educação freiriana: "crítica, progressista, transformadora, radical, questionadora, estimulante", mas também relacionada aos conceitos e conteúdos. Dado o contexto autoritário e desfavorável à educação, indicam que ela passa seu pior momento, é atacada a todo instante. Mas também atrelam a ela as unidades de registro: "sonho" e "sonho embasado historicamente", ou seja, a esperança no futuro e na transformação também em uma dimensão freiriana.

A categoria "Esperança" embora apareça representada por poucas unidades de registro, "esperança nas mudanças", "contra-sonhos”, está presente enquanto sentido em todas as cartas, especialmente ligada à categoria "educação", que é colocada como motor de mudanças sociais e possibilidade efetiva de transformação do mundo e das pessoas. Essa categoria está bastante representada no pensamento de Freire, especialmente na sua defesa pelo caráter utópico da educação. Na obra "Pedagogia da Autonomia", Freire (2001, p. 80-81) afirma que o ato de ensinar exige alegria e esperança, indicando a esperança como uma base epistêmica do ser humano:

Há uma relação entre a alegria necessária à atividade educativa e a esperança. A esperança de que o professor e alunos juntos podemos aprender, ensinar, inquietar-nos, produzir e juntos igualmente resistir aos obstáculos à nossa alegria. Na verdade, do ponto de vista da natureza humana, esperança não é algo que a ela se justaponha. A esperança faz parte da natureza humana. Seria uma contradição se, inacabado e consciente do inacabamento, primeiro, o ser humano não se inscrevesse ou não se achasse predisposto a participar de um movimento constante de busca e, segundo, se buscasse sem esperança. [...] A esperança é um condimento indispensável à experiência histórica. Sem ela, não haveria História, mas puro determinismo. Só há História onde há tempo problematizado e não pré-dado. A inexorabilidade do futuro é a negação da História. 
Num sentido antitético, ao mesmo tempo que os mestrandos situaram a esperança como algo essencial, apontam de maneira bastante contundente a "Desperança" e o "Medo", em um momento histórico que caracterizam como: "Momentos tenebrosos; tempos sombrios; tempos difíceis; tempos nebulosos". Apontam que "o século XXI assombra", traz medos e incertezas, situando-o como uma época turbulenta, de extremos. Nesse contexto difícil em que situam as incertezas do rumo educacional do país, marcado pela opressão e negligência, apontam os traços da desesperança e do desânimo. A palavra medo aparece sete vezes em textos diferentes e articulada, ou seja, com coocorrências das expressões já indicadas: "Momentos tenebrosos; tempos sombrios; tempos difíceis; tempos nebulosos". Sobre a desesperança Freire (2001, p. 81, grifo do autor) declara:

É preciso ficar claro que a desesperança não é maneira de estar sendo natural do ser humano, mas distorção da esperança. Eu não sou primeiro num ser da desesperança a ser convertido ou não pela esperança. Eu sou, pelo contrário, um ser da esperança que, por "n" razões, se tornou desesperançado. Daí que uma das nossas brigas como seres humanos deva ser dada no sentido de diminuir as razões objetivas para a desesperança que nos imobiliza.

Em Pedagogia do Oprimido, Freire (1988) destaca o "medo da liberdade" manifestado por pessoas em processos de alfabetização ou cursos de capacitação, que indicam os perigos da conscientização como expressão dos processos de opressão pelos quais passam, dos quais decorre a consciência ingênua, carregada pelo medo e pela inconsciência da força, do potencial de mudança que cada ser humano carrega. O medo para Freire está diretamente ligado ao contexto e às práticas da opressão. Algo que os(as) mestrandos(as), enquanto professores(as), estão sentindo profundamente e manifestando nas cartas, nesses tempos de desvalorização e agressões contínuas à educação, ao conhecimento, à arte, à cultura e à ciência.

Na categoria "Mudanças/Transformações", os(as) mestrandos(as) manifestam a importância e necessidade, em face aos perigos e riscos de tempos difíceis, da intensificação das lutas pelos direitos e pela democracia. Ou seja, a necessidade de não fugir aos desafios, de constituir utopias, para a manutenção dos sonhos e projetos, num Brasil em que extrema direita ganhou destaque e voz por representar ideias conservadoras de uma parcela da população, que não é a sua maioria, mas que se porta como tal. São categorias que expressam diretamente as obras de Freire, em especial, as informações trazidas em "Educação e Mudança", na qual o autor situa 
a educação como elemento central da mudança social, na medida em que instrumentaliza os sujeitos sociais para atuar no meio e transformá-lo. (FREIRE, 1984).

A categoria “democracia/democratização" está articulada às mudanças e transformações, pois traz unidades de registro que apontam para a resistência à opressão atual: "resistência às desigualdades"; "movimentos sociais"; "minorias"; "liberdade"; "escolha e decisão". Aponta como caminhos democráticos a responsabilidade humana coletiva, a eticidade e a educação igualitária.

A categoria "consciência humana" presente nas cartas dos(as) mestrandos(as) é um dos pontos centrais da teoria de Freire, que toma a educação como um processo de conscientização. Ele apresenta três estados de consciência: consciência intransitiva; transitiva e crítica. As duas primeiras são consciências ingênuas, ou seja, analisam a realidade de modo simplista, com conclusões superficiais ou apressadas, tendem a aceitar as formas gregárias de massificadoras de comportamento, não valorizam a ciência, pois se contentam com explicações "mágicas"; partem do pressuposto que sabem tudo, sem manifestar fundamentos para a sua argumentação; apresentam forte conteúdo passional e percepção estática, não mutável da realidade (FREIRE, 1984, p. 40). Esse estado de consciência parece ter sido retomado na sociedade contemporânea nos últimos anos e tem florescido nas redes sociais e mídias, acompanhado das Fake news ${ }^{5}$ e da chamada "pós-verdade" (PRIOLLI, 2017). Caracteriza muito bem as manifestações da extrema direita em diferentes locais do mundo.

A consciência crítica é apresentada por Freire com características opostas: busca a análise de problemas em profundidade e toma a realidade como mutável; procura embasar seu pensamento na ciência, buscando a verificação e testagem dos fatos; não reconhece verdades absolutas; repele posições de acomodação; é indagadora, investigativa, dialógica (FREIRE, 1984, p. 41). É nessa percepção que a categoria "consciência humana" é abordada nas cartas pelos(as) mestrandos(as), que a aproximam da reflexão, da criticidade, da consciência de classe; da consciência de sua própria incompletude, que aparecem como unidades de registro.

Sobre a reflexão, vale lembrar as palavras de Freire (1984, p. 16): “A primeira condição para que um ser possa assumir um ato comprometido está em ser capaz de agir e refletir".

Na categoria "professores(as)/educadores(as)" os(as) mestrandos(as) apontam polos positivos e negativos. No polo negativo constam as unidades de registro: "Desesperançados; acomodados; oprimidos"; "Exilados dentro do nosso país; exilados 
dentro das cercas ideológicas violentas", aparece, ainda, a expressão “doutrinadores”, algo bastante defendido pelo movimento "Escola sem partido". Essas unidades de registro refletem a situação atual de polarização ideológica e ataque aos educadores. No polo positivo, salientam-se educadores(as) em uma perspectiva progressista, libertadora: "Comprometidos com a educação, mundo, realidade, justiça; não podem ser meros transmissores de conteúdos programáticos", interessados em "retirar as vendas colocadas nos alunos".

$\mathrm{Na}$ categoria "aluno/estudante/crianças/jovens" também se manifestam polos positivos e negativos. No polo positivo, os(as) estudantes são apontados como aqueles que ainda têm sede de mudanças e vivência democrática, sujeitos que devem ter direito à educação, devem ser estimulados pelos professores a pensar criticamente e superar a postura fatalista; requerem uma formação que os estimulem. Já no polo negativo, são vistos, genericamente, como portadores de um estado de consciência ingênua, ou seja, não possuem consciência de classe; são "objetos" dentro da sociedade; apresentam falta de coragem dada pela situação econômica e social. Há outro aspecto que é trazido em relação à educação das crianças pequenas, é a "tirania da liberdade" - expressão de Freire - havendo menção da imobilidade dos pais em face aos desejos e imposições dos filhos e a observação de que dar amor é dar limites. Essa última percepção se coaduna muito com trechos da primeira Carta Pedagógica em que Freire discute o delicado limite entre autoridade e liberdade e questiona que as crianças não aprenderão democracia na licenciosidade, assim como não aprenderão a decidir, se lhes for negada a palavra. Defende então:

[...] É vivendo com lucidez a tensa relação entre autoridade e liberdade que ambas descobrem não serem necessariamente antagônicas uma da outra.

É a partir deste aprendizado que ambas se comprometem na prática educativa com o sonho democrático de uma autoridade ciosa de seus limites em relação com uma liberdade zelosa igualmente de seus limites e de suas possibilidades. (FREIRE, 1984, p. 35).

A categoria "riscos/perdas" não apresenta polo positivo, mas acentua os aspectos negativos vivenciados pelos(as) mestrandos(as), algo já colocado parcialmente em outras categorias, especialmente em "desesperança e medo". As unidades de registro denunciam situações presentes em 2019, quando foram elaboradas as cartas e, infelizmente, agudizadas desde então: "guerra ideológica; polarização"; "intensificação da alienação"; "ridicularização da consciência crítica"; "retirada de direitos; enfraquecimento da luta social"; "perdas de conquistas de movimentos 
sociais"; "perda de vidas; perdas da democracia; perda da liberdade de expressão"; "elite maximizadora de injustiças" e "Escola sem partido".

Essa análise global das cartas aponta para a ciência dos(as) mestrandos(as) em relação aos problemas contemporâneos e como afetam seu fazer, sua identidade e sua existência. Mas também a presença de uma consciência crítica que defende $o$ caráter transformador e utópico da educação, a possibilidade de mudar o mundo, ou seja, a percepção freiriana, que permite aos mesmos terem sonhos e esperança.

Em uma análise posterior, as cartas foram subdivididas e identificadas por letras e números, C (carta), A (carta 01), B (Carta 2), C (Carta 3), D (Carta não identificada), os números indicam a quantidade de cartas de cada categoria ${ }^{6}$. Nessa análise buscou-se identificar as unidades de contexto, com a análise de fragmentos dos textos.

A primeira carta foi respondida por sete mestrandos (CA01 a CA07), a segunda por outros sete mestrandos (CB01 a CB07), a terceira por um mestrando (CC01). Nas três cartas restantes (CD01 a CD03), não há referência de resposta à uma carta em especial, mas comentários gerais sobre as ideias de Freire.

Em nove delas há agradecimentos ao autor e reconhecimento da importância e validade da sua obra. Alguns apontados abaixo:

Querido Paulo Freire, acabo de ler a sua primeira carta, do seu livro Pedagogia da Indignação e fico impressionada com a sua capacidade de provocar reflexões tão valiosas e oportunas para os nossos dias. [...]. [CA01].

É um privilégio ter a oportunidade de ler tuas cartas tão precisas e exatas, sem dúvidas tu és um homem de grande sabedoria que deixou marcas históricas na vida de muitas pessoas. [CA04].

As suas obras nos levam à uma reflexão, pois já vivemos momentos tenebrosos e nunca se perdeu a esperança de mudanças. Eu agradeço a sua grande contribuição para a minha formação enquanto cidadão e professor. Obrigado! [CA06].

Caro Paulo Freire!

Já começo te agradecendo as contribuições nas cartas. [CA07].

Reafirmo o encantamento ao ler seus escritos e digo que o exemplo dado sobre o Movimento dos Sem-Terra, quanto ao seu determinismo e respeito pelo outro em suas lutas, descrevendo a intenção destes em transformar o mundo para todos, desacreditados no 'fatalismo neoliberal' como 'neobobismo', reacende em nós a esperança de somarmos força para lutar em prol de um país mais justo, mais fortalecido, principalmente no que tange à educação. [CB02]. 
[...] quero externar a minha admiração pelo seu legado e pelo seu trabalho como professor pesquisador na área da educação. Que suas obras continuem inspirando outros profissionais para que as transformações sejam possíveis tanto quanto necessárias. [CB04].

[...] gostaria de agradecer a sua coragem. Por meio dela nos tornamos mais fortes. Seu discurso encorajou-nos e acordou em nós o sonho de mudança. O caminho é longo. Mas você não parou, então não vamos parar. A educação vale a pena. A marcha vai continuar, para manter os direitos que temos, e para conquistar o que é nosso por direito. Viva a educação Freire! [CB07].

[...] Aqui no Brasil, infelizmente não conseguimos adotar seus ensinamentos, questões políticas falam mais alto e a população ainda não conseguiu se libertar da ignorância, logo, a opressão ainda impera em nosso país. Mas seu legado é valorizado, o mundo inteiro fala de você e respeita seu trabalho, todas as universidades do mundo reconhecem a importância do seu trabalho, aqui você é Patrono da Educação e suas contribuições são importantíssimas. [CD01].

Os mestrandos reforçam o reconhecimento da importância da obra de Freire, em âmbito nacional e internacional, ratificando as percepções presentes na produção científica do ensino de ciências no Brasil (RICARDO, 2003; AULER; DELIZOICOV, 2006 ; GALIETA NASCIMENTO; VON LINSINGEN, 2006; SANTOS, 2007; AULER, 2013; ZAUITH; HAYASHI, 2013;) e, especialmente, dos teóricos que trabalham na perspectiva do Movimento CTS (Ciência, Tecnologia e Sociedade) e CTSA (Ciência, Tecnologia, Sociedade e Ambiente), que salientam a consonância entre a epistemologia e a pedagogia de Freire e os princípios que regem esses movimentos.

Em algumas cartas, há uma menção direta às críticas atuais sobre a obra e o próprio Paulo Freire, e a indicação de que partem de setores não democráticos da sociedade:

Eu sei que você deixou para nós o método com seu nome, mas esse conjunto de ideias até hoje recebe muitas críticas, mesmo que você tenha sido considerado um dos maiores educadores do país, com toda a sua luta pela democratização do ensino [...]. [CA07]

Vivemos tempos sombrios, tanto de consciência política, como na Educação. Um setor da sociedade que não conheceu tua obra e nem seu pensamento pedagógico, generoso e esperançoso, estão pedindo em manifestações públicas e 'democráticas' um 'basta a Paulo Freire' e volta da ditadura militar alegando que você era marxista e que os professores são doutrinadores. [CD02]

Mudar o mundo continua sendo tão difícil quanto possível. Essas foram suas palavras na primeira carta pedagógica do livro "Pedagogia da indignação" e nunca pensei que suas ideias seriam tão atuais como estão sendo agora. Talvez seja por isso que você ainda é alvo da tirania de um governo repressivo e autoritário, como esse que preside o país. [CB04] 
[...]. Nas escolas, muitos professores são chamados de doutrinadores ao disseminarem o seu método e suas ideias, pois elas são vistas como ideológicas e partidárias. Por isso, uma das discussões recentes envolveram a retirada do seu nome como patrono da educação brasileira. É triste pensar que seus ideais sejam ainda mal interpretados e difamados por pessoas que desconhecem o seu legado e suas contribuições para a educação. [...]. [CB04]

Essa perspectiva dos mestrandos também encontra eco na percepção de autores das áreas de ensino e educação, que externam críticas ao governo atual em relação ao desconhecimento acerca da obra de Freire e/ou leitura equivocada. Em face aos constantes ataques contra Freire, o Instituto Paulo Freire publicou em 2019 uma coletânea com sessenta e três artigos que contestam as críticas imputadas à Freire, consideradas pelos autores como parte das fake news. Muitos dos autores nessa coletânea discutem o crescimento das fake news, a partir da chamada pós-verdade, que para Priolli (2017) é o momento em que a verdade é apenas mais uma opção em pauta, ou seja, admitem-se falsas informações desde que atendam a determinados interesses. $\mathrm{O}$ autor discute o surgimento do termo a partir da sua inserção no Dicionário Oxford, que o conceitua como “[...] um adjetivo relacionado ou evidenciado por circunstâncias em que fatos objetivos têm menos poder de influência na formação da opinião pública do que apelos por emoções ou crenças pessoais" e também aponta para a sua disseminação a partir de 2016, embora tenha sido cunhado em 1992. Priolli (2017, p. 1, grifos do autor) comenta ainda, que:

Na definição britânica, "pós-verdade” é um adjetivo “que se relaciona ou denota circunstâncias nas quais fatos objetivos têm menos influência em moldar a opinião pública do que apelos à emoção e a crenças pessoais".

Não seria então, exatamente, o culto à mentira, mas a indiferença com a verdade dos fatos. Eles podem ou não existir, e ocorrer ou não da forma divulgada, que tanto faz para os indivíduos. Não afetam os seus julgamentos e preferências consolidados.

Souza (2019, p. 57) situa outro ponto essencial para a análise desse movimento social: "Saliente-se que na conjuntura da pós-verdade, os homens são levados a considerar como mentira as coisas que não se coadunem com a própria 'verdade', distanciando-se da intersubjetividade e da prática do diálogo”.

Entre os artigos da coletânea, destaca-se o de Leite (2019), que descreve os problemas trazidos pelas fake news, relacionando-os com as ações impróprias em eleições que permitiram o crescimento de partidos de direita e situa a importância 
de Freire para os educadores trabalharem de forma ética e crítica com as tecnologias digitais. Sobre as críticas desferidas ao autor, ela comenta:

Particularmente no Brasil, um outro caso que demonstra o poder deletério do uso das redes para fins pouco democráticos são as calúnias sobre um dos mais importantes educadores brasileiros, reconhecido mundialmente por suas contribuições para a história das ideias pedagógicas, mas que no Brasil tornou-se alvo de difamação. Paulo Freire, que em 2012 foi declarado o patrono da educação brasileira (Lei oㅡ 12.612 de 13/04/2012), e que neste ato teve reconhecida sua trajetória de vida dedicada à alfabetização e educação libertária de jovens e adultos, acabou se tornando munição para atacar iniciativas pedagógicas que questionam uma educação bancária, termo cunhado pelo próprio Paulo Freire, em que o estudante é apenas um depósito de conteúdos. Taxado de doutrinador e comunista pelo próprio Presidente da República, uma onda de desinformação em torno das ideias freirianas acabou se espalhando em forma de falsas notícias. Sem o devido conhecimento de sua obra, muitas pessoas repercutem essas falácias.

Em nossa sociedade, não é difícil concluir o que transcorre nos bastidores dessa manobra de ataque ao pensador. Se o que Freire desejava era ensinar aos oprimidos e excluídos os caminhos para a emancipação, para o pensamento crítico e consequente libertação frente a possíveis injustiças sociais, parte de uma classe dominante da sociedade capitalista preferiu, então, torná-lo um inimigo do país. Entender os motivos que levam à criação deste tipo de engodo e saber distinguir a diferença entre opinião e informação, verdade e mentira, notícia falsa ou verdadeira acaba sendo uma habilidade crucial para que indivíduos saibam se posicionar frente à própria realidade. Freire mesmo sugeria que nos colocássemos frente às situações do mundo munidos de algumas perguntas: Por quê? A favor de quê? Para quem? A favor de quem? Contra o quê? Contra quem servem estas mentiras que estão sendo criadas e reproduzidas? (MOTA, 2020, p. 14).

Arrais e Bizerril (2020) apontam os múltiplos retrocessos na Educação Ambiental a partir de 2016, movidas pelas ações de desmonte da agenda Ambiental, por parte do Ministério do Meio Ambiente, por meio da extinção de cargos, demissão de técnicos qualificados, extinção de ações e projetos voltados à preservação ambiental, descrédito do governo sobre dados oficiais do INPE relacionados ao desmatamento, queda da fiscalização e aumento da impunidade. Consideram, ainda, que a ação conservadora em muitas áreas traz consequências negativas ao meio ambiente:

[...] O ataque ao meio ambiente também se dá indiretamente por diversas outras manifestações do governo tais como tentativas de criminalização dos movimentos sociais, de desmonte e desmoralização das universidades públicas e institutos federais, e consequentemente da ciência, afronta aos quilombolas, ribeirinhos, indígenas e LGBTQI+, ataques à classe dos professores e a figuras educadoras de destaque como Paulo Freire, desdenho com a historicidade dos direitos humanos e na busca de um realinhamento ideológico do país aos Estados Unidos da América, sobretudo 
ao governo de Donald Trump (DICKMANN; CECCHETTI, 2019; LEHER, 2019, grifo nosso).

Outro aspecto presente em várias cartas foi a indicação da atualidade das ideias de Paulo Freire lançadas em 1977:

Gostaria de poder lê-lo com mais frequência e intensidade, pois as suas contribuições transpassam gerações e épocas. Continuam muito atuais. Espero encontrá-lo novamente por meio da leitura. Assim, continuarei a aprender com você. [CA01]

Estamos em 2019 e como educadora, inicio essa carta dizendo que pouca coisa mudou por aqui desde a sua partida. [...]. Infelizmente o mundo continua pautado em uma ética de mercado, uma ditadura mercantilista; poucos se baseiam na ética humana sem se importar com a democracia autêntica e genuína. [CA05]

Assimilo as suas inquietações sobre o contexto social e político de sua época, o que é tão oportuno para o período ao qual estamos vivendo no Brasil e mundo atualmente. [...]. [CB01]

Talvez hoje não esteja tão diferente que [no] dia 21 de abril de 1997, [quando] onde [sic] um índio foi assinado sem pudor. $O$ sangue de inocentes continua sendo derramado [...]. [CC01]

Lamento dizer que você previu com muita convicção os acontecimentos que assolam os dias de hoje. Nesses vinte anos da sua partida, a educação sofreu muitas transformações no que diz respeito a avanços significativos e satisfatórios de acordo com a sua percepção. Após uma década, parecia que as indignações reveladas por ti teriam possíveis soluções em longo prazo; a esperança era maior. Contudo ainda havia falhas como toda proposta. O século XXI assombra, traz medo e incertezas. [...] [CA02]

Embora não possamos analisar a realidade de forma anacrônica, vale lembrar que, considerado o modo de produção, continuamos no sistema capitalista e com a agudização do neoliberalismo, especialmente após o avanço significativo das forças conservadoras em muitos países, inclusive no Brasil. Foram também forças conservadoras que geraram o exílio de Paulo Freire, nos anos 1960, mas é preciso distingui-las das forças atuais. Essas forças são tratadas na produção científica contemporânea como "nova direita", "extrema direita" (CÊPEDA, 2018).

Lowy (2015 apud CÊPEDA, 2018) reflete sobre o avanço da extrema direita, com padrões diferentes em contextos e grupos nacionais diversos, mas ligados ao fascismo. Observa que desde 1930 não havia manifestações expressivas do fascismo até os anos 2000. Cêpeda (2018, p. 46) ao analisar as ideias de Lowy, destaca sua percepção sobre o contexto europeu: 
[...] Sobre a Europa alinhava uma miríade de combinações de variáveis, enfeixadas em países com a presença de organizações partidárias de caráter: fascista e/ou neonazista, semifascista ou de extrema-direita. As variáveis mais comuns e que ordenam os modelos são: nacionalismo, antiglobalismo, xenofobia, racismo explícito, retórica anti-imigrante, islamofobia, beligerância e intolerância. Variam também na percepção das disrupturas do capitalismo, no caráter antissistêmico ou institucional, na aversão ao comunismo e na seleção do inimigo - interno e externo. O trabalho de Lowy estabelece a correlação entre direita (extremada) e as bases ideológicas do fascismo, atualizando seus nexos e sentido.

Portanto, as condições conjunturais descritas por Freire apresentam aspectos similares, mas com traços de piora e de forma muito devastadora no âmbito das políticas sociais. Revisitando Hobsbawm (2002), no século XXI, vivemos em tempos desinteressantes, em que crenças nas esferas democráticas estão se perdendo e há uma realidade virtual, composta por "verdades" não objetivas, pós-verdades, que é devastadora, pois retira dos sujeitos sociais pontos essenciais de equilíbrio para a vida em sociedade, entendida como sociedade de direito.

O caráter do retrocesso e da desestruturação social e no âmbito educacional são também manifestados na maioria das cartas, de formas diferentes, mas com alguns aspectos em comum, como a quebra de valores morais, os riscos e problemas trazidos pela polarização política (direita e esquerda), a guerra ideológica, expressos nos trechos a seguir:

[...] Vivemos em uma época turbulenta em que os extremos são balançados a cada momento, a ponto de explodir, danificando com estilhaços as proximidades. A educação sofre seu pior momento, é atacada a todo instante e o pior, por quem deveria acreditar nela. A construção do sujeito crítico é piada, a criticidade é vista como massa de manobra de quem quer ver um caos no mundo, aterrorizados por pensar que o desenvolvimento não acontecerá se continuarmos a acreditar em 'utopias'. Vejo educadores desesperançosos, oprimidos em suas salas de aula com receio de pedir lição de casa para seu aluno. A formação de professores é vaga, sem tempo hábil e sem investimentos. Ser professor no nosso país é a segunda opção na escolha de uma profissão. [...]. [CA02]

A guerra ideológica entre direita e esquerda nos leva a grandes perdas, as pessoas não enxergam a gravidade e a complexidade dos problemas, e isso tem se refletido na educação. O governo encara [como] gasto e não investimento, a carreira do professor é desvalorizada, e o governo atual encara com desprezo, e isso cada vez mais aumenta a desigualdade social. A concentração de renda está cada vez mais em pequenos grupos que são responsáveis pela tomada de decisões, sem se preocupar com a grande parte da sociedade. Tenho medo, a função da escola está fadada ao não cumprimento, é esse o interesse de alguns políticos. [CA06] 
São tempos nebulosos e tenho certeza de que, se estivesse vivo, sua luta pela consciência crítica e pelos 'esfarrapados do mundo' seria tão constante como foi no passado. [...]. [CB04]

[...]. Nesses últimos três anos, o Brasil passou por transformações que estão acabando com a cultura e o progresso do país e isso em diversos aspectos, como políticos, sociais, ideológicos, educacionais, familiares, éticos, etc., estamos vivendo um período de retirada de direitos e do enfraquecimento da luta social e isso, por causa de uma intensificação da alienação de uma parte da sociedade brasileira, que acredita que essas lutas não trarão mudança e se contenta com as migalhas que as grandes corporações, políticos e mídia jogam a esses cidadãos. [CB05]

[...] O atual governo, tal como aquele operante em sua época, não deseja cidadãos críticos, que tenham a noção de como são oprimidos. Querem reproduzir um discurso de ódio e plena aceitação de uma realidade que prejudica a todos, inclusive a natureza. Temos medo. Mas estamos alicerçados na ideia de que só tem coragem quem um dia teve muito medo. [...].

[...] Nós, professores estamos sendo exilados. Exilados dentro de nosso país. Exilados por não poder abordar temas significantes, exilados por não termos o reconhecimento necessário, exilados dentro da cerca de ideologias violentas as quais fomos expostos. [CB07]

[...] Estamos passando por tempos difíceis, com lutas intensificadas e recorrentes, mas em muitas situações fadadas a falta de um objetivo em comum a todos os brasileiros. Nesses últimos três anos, o Brasil passou por transformações que estão acabando com a cultura e o progresso do país e isso em diversos aspectos, como políticos, sociais, ideológicos, educacionais, familiares, éticos, etc., estamos vivendo um período de retirada de direitos e do enfraquecimento da luta social e isso, por causa da intensificação da alienação de uma parte da sociedade brasileira, que acredita que essas lutas não trarão mudança e se contenta com as migalhas que as grandes corporações, políticos e mídia jogam a esses cidadãos. [CB05]

Esses aspectos descritos nas cartas dos mestrandos e muitos outros são pontuados nos escritos de vários autores (CÊPEDA, 2018; SANTOS; PEREIRA, 2018; CESLAGHI, 2019; LEHER, 2019; MACEDO, 2019; TAFFAREL; NEVES, 2019; REIS, 2019; SEVERO, 2019; NACIF; SILVA FILHO, 2019) que analisam as políticas educacionais brasileiras pós 2016 e destacam questões preocupantes. Alguns dos elementos mais citados pelos autores são: os riscos à democracia e à liberdade; a doutrinação ideológica conservadora proposta como ação neutra e marcada pelo descrédito à ciência, pela crescente militarização e pela influência religiosa em assuntos educacionais; os cortes orçamentários e os problemas no financiamento da educação dados pelo teto de gastos, contingenciamentos e descaso com o FUNDEB; os ataques à ciência, à cultura, à educação e, por consequência, aos educadores e às 
escolas; o desencontro de ações do governo federal, movido por três grupos distintos e dissonantes, que se materializa também no Ministério da Educação, que sofre apagão operacional nunca visto.

Taffarel e Neves (2019, p. 317-319) ao analisarem a conjuntura educacional após a eleição de Jair Bolsonaro, destacam parte desses aspectos, bem como os processos de precarização e privatização da educação:

A avaliação da conjuntura educacional apresenta fatos que permitem afirmar que a Educação Estatal, pública, inclusiva, laica, democrática, de qualidade e socialmente referenciada, em patamares conseguidos nos últimos governos de Luís Inácio Lula da Silva e Dilma Rousseff, está sendo destruída.

São evidências dessa destruição, a implementação da política neoliberal radicalizada que preconiza privatizar, desmontar o patrimônio público, entregar as riquezas e abrir o Brasil ao capital imperialista predatório e parasita.

São evidências: a aprovação de medida de entrega do pré-sal ao capital internacional; o não cumprimento das metas do Plano Nacional de Educação; a alteração dos perfis dos componentes do Conselho Nacional de Educação - CNE e do Fórum Nacional de Educação, com a entrada dos empresários do setor privatista da educação (Todos pela Educação) e a indicação de um militar para a Secretaria Executiva do CNE; a aprovação da Reforma do Ensino Médio; a aprovação da autoritária e esvaziadora do currículo Base Nacional Comum Curricular (BNCC), aprovação da Emenda Constitucional 95/16 que institui o ajuste fiscal e limita investimentos em educação e saúde; aprovação das medidas que permitem a terceirização sem limites, que precariza o trabalho docente; a aprovação da reforma trabalhista, que atinge os trabalhadores em geral e em especial os trabalhadores da educação, o exercício do magistério, o trabalho docente, pois retira dos professores o atual modelo de aposentadoria aumentando o tempo mínimo de serviço necessário para que o docente tenha direito a aposentadoria.

Mas, existem outras medidas específicas que estão atingindo a Educação, desde a creche, passando pela educação de jovens e adultos e alcançando o ensino superior. Elas estão relacionadas ao financiamento da Educação, da Ciência e da Tecnologia, a gestão, a formação inicial e continuada dos professores e professoras, ao trato com o conhecimento científico, ao currículo escolar, aos métodos e técnicas de ensino, à censura nas escolas, à negação da ciência, ao projeto Escola Sem Partido, a educação domiciliar, a militarização das escolas públicas, ao ataque ao direito de cátedra, ao ataque a autonomia dos sistemas de ensino e, em especial, nas universidades, a autonomia de gestão, administração, financeira e didático pedagógica.

As marcas de um momento histórico de retrocessos, avanços contra a democracia, a vida, as minorias, a natureza, estão presentes nas cartas, mas da mesma forma, há muitas manifestações sobre a necessidade e importância da transformação, da esperança, das utopias e dos sonhos, como projetos a serem concretizados: 
Entendo que não há luta sem sonhos. E que esses sonhos são projetos pelos quais almejamos e acreditamos. Assim, os tornaremos reais à medida que nos ampararmos na autenticidade. Nessa perspectiva, caro Paulo, a tão sonhada mudança não tardará!

Prova disso são os movimentos sociais, que constituem a estratégia mais adequada de luta e defesa dos direitos das pessoas, especialmente àquelas que não possuem poder aquisitivo ou mesmo político. Refiro-me às minorias oprimidas da sociedade que fazem desses movimentos a ponte de acesso à democracia. [CB01].

Percebi o quão é importante sonhar, mas um sonho embasado historicamente nas condições dos contextos materiais, tecnológicos e científicos, nos quais estamos inseridos. $[\ldots]$.

É fato que o nosso passado deixou marcas que perduram até hoje, tais como a colonização e escravidão, que dificultam a mudança. Mas se decidirmos agir de forma progressista, não há hora e nem lugar e muito menos importa quem eu sou. O importante é que eu saiba que a luta, seja ela ideológica, política, pedagógica ou ética, deve ter como principal foco o respeito ao outro. [CB02]

Outro ponto fundamental tratado em sua carta pedagógica, professor Paulo, seria o reconhecimento do ser humano enquanto projeto, o que remonta ao coerente entendimento de que o ser humano não é uma obra acabada, isto é, podendo reformular-se e reavaliar-se no decorrer da vida, o que, por interpretação, requer a aceitação de que suas mutantes facetas e ações são instrumentos de transformação do mundo. [...].

Dessa forma, prega-se o estímulo à ação transformadora do ser humano, em detrimento da visão determinista de que as coisas são como deveriam e que, portanto, nada se pode fazer. A ascendência e o exercício de uma educação estimuladora da autonomia humana e de sua possibilidade de intervenção transformadora no mundo, de modo que habilite este para o pleno exercício da cidadania. [CB03]

Em sociedade e dentro de sala [de aula] atualmente, luto por melhorias para que meu aluno possa ver além dos antolhos que lhes são colocados. É um processo lento e que emana, analogicamente, trabalhar plantando as sementes e cuidar para que elas germinem, gerando assim um cidadão capaz de atuar criticamente, que tenha consciência de que é parte da sociedade, que suas ações causam consequências que atingem a todos, pois ele faz parte desta em sua totalidade, para que assim esse indivíduo não renuncie à capacidade de pensar, de conjecturar, de comparar, de escolher, de decidir, de projetar e de sonhar. [CB05]

Apesar de parecer utópico, concordo com o senhor de que devemos sonhar mantendo lealdade às condições históricas, materiais, aos níveis de desenvolvimento tecnológico e científico do contexto vivenciado. Dessa forma, podemos criar projetos e lutar pelas mudanças [acreditando] que, apesar dos diversos obstáculos, é preciso perseverar e ter em mente que somos condicionados pelas estruturas econômicas e políticas, sendo que apenas estando cientes disso, conseguiremos enxergar a realidade em que estamos inseridos e nos tornar capazes de [nela] intervir. [CB06]. 
Nessa mesma esteira de esperança e de percepção da possibilidade das mudanças, por meio de intervenções sociais, os mestrandos salientam o papel da educação no processo de conscientização dos aprendizes enquanto sujeitos sociais, políticos e históricos e em uma percepção libertadora e emancipatória -o caminho freiriano - manifestado em trechos como:

[...] se desejamos que o processo de transformação do mundo realmente tenha um fundamento, é preciso formar, construir uma consciência democrática desde cedo em nossos alunos. No entanto, para que isso aconteça, a escola deve contribuir e desenvolver metodologias pautadas em valores como respeito, responsabilidade, honestidade, solidariedade e justiça, enfim, todos aqueles valores que auxiliem a formação de uma mentalidade e atitude democrática.

Esse desenvolvimento da formação da consciência democrática baseia-se exatamente nos quatro conceitos que Paulo Freire cita ao longo dessa carta. O primeiro deles, a liberdade, tão particular e contraditória, exige cuidados para não se tornar licenciosidade e afetar o próximo.

O segundo conceito, a autoridade, vem sofrendo uma distorção e virando autoritarismo, cotidianamente, vivenciamos cidadãos implorando vontades, ideias e muitas vezes calando a voz do outro. Escolha e decisão são conceitos fundamentais à vida, por meio deles é possível direcionar objetivos e traçar o futuro.

Sabemos qual a importância desses conceitos na educação e na vida e, como educadores, devemos trabalhá-los associados aos próprios conteúdos, não perdendo [de vista] a função principal da escola que é a de desenvolvimento do conhecimento científico, crítico e reflexivo. [CA05].

[...] Particularmente me sinto motivado ao saber que faço parte do grupo que acredita no sonho do amanhã e que busca modos de concretizá-lo, ao passo que também compreendo os fatores que tentam limitar o desenvolvimento da consciência crítica do oprimido, frente à necessidade de controle dos opressores. [...].

Sigo concordando fielmente com a sua ideia de que o foco dessa educação crítica não é a imposição ideológica e nem sobre uma única forma de ler o mundo, assim como eu também não acredito que o papel da educação se restrinja ao ensino de conceitos. Não posso silenciar as injustiças sociais do mundo e ser mero transmissor de conteúdos programáticos, enquanto o poder da elite continuar maximizando essas injustiças. [CB04].

A gente acha que ainda tem jeito, e sabe que eu acho que tem mesmo. Na educação, na forma de pensar, na união, na luta, é só não deixar de falar, e assim a gente vai indo nesse mundo que parece tão feroz, a gente vai acreditando, nem que seja por um pingo, que ainda tem gente que pensa como nós, eu, educador, e como tu mesmo já dizia: "Se a educação sozinha não transforma a sociedade, sem ela tampouco a sociedade muda". [CC01] 
As cartas expressam um rico momento de troca entre educadores(as), registram diálogos que partilham angústias, desalentos, dúvidas, mas também esperança dada pelo exemplo de Freire e tomada pelos(as) mestrandos(as) como caminho possível em tempos difíceis.

\section{Considerações finais}

As cartas de Paulo Freire e a Paulo Freire reafirmaram a atualidade e importância da sua obra, especialmente em um momento de crescente opressão. Os diálogos dos(as) mestrandos(as) com o autor, denotaram a compreensão de categorias caras à Freire e o desenvolvimento mais acentuado da consciência crítica, mediante a análise da complexa realidade vivida por eles(as). O que permite afirmar que os objetivos da atividade foram plenamente atingidos.

As principais categorias que emergem das cartas apresentam uma polarização positivo-negativa: esperança/desesperança; conservadorismo/necessidade de mudar o mundo; medo/sonhos. Essa polarização, porém, não é lida como mera oposição, mas em sua relação dialética, na qual um polo nega e revê e modifica o outro. São categorias que lembram relações já colocadas por Freire em "Educação e mudança": saber-ignorância; amor-desamor; esperança-desesperança (FREIRE, 1984).

Sobre a relação esperança-desesperança, são essenciais as palavras de Freire:

Com base no inacabamento, nasce o problema da esperança e da desesperança. Podemos fazer deles o objeto de nossa reflexão. Eu espero na medida em que começo a busca, pois não seria possível buscar sem esperança.

Uma educação sem esperança não é educação. (FREIRE, 1984, p. 29-30).

Por uma educação com esperança e por educadores(as) conscientes de seu papel e compromisso social é que trabalhamos. Graças à Freire, marco essencial para a educação de todos os povos e lugares, com maior consciência de nossa capacidade de mudar a nós mesmos e ao mundo que nos cerca. 


\section{Letters to Paulo Freire: (un)hope of teachers in uninteresting times}

\section{Abstract}

The article retract a pedagogical experience carried out within the scope of the Theories of Learning, in a Professional Master's Course in Science Teaching, from a federal public institution in Mato Grosso do Sul. The graduate students were asked to write a letter answering to one of the three Letters present in the work "Pedagogy of indignation: teaching letters and other writings", by Paulo Freire. The activity had an objective to analyze the current situation of life and education of teachers, assuming Freire's theory, through Freire's favorite textual genre: the letters. Eighteen Master's students participated in the activity, most of them teachers from public schools, who teach Biology, Chemistry, Physics and/or work in the early years of elementary school, as conducting teachers. The analysis of the letters was done through the categorical analysis of Bardin (2016), observing the pre-analysis, the exploration of the material and the treatment of the results, the inference and the interpretation. In the exploration of the material, the set of information was first analyzed, looking for categories, units of record and their frequency, and subsequently, they were grouped into three groups, having as reference Freire's letter answered by the master's students. Have been identified to the following categories: Paulo Freire, Education, Hope, Despair/fear; Changes/transformations; Democracy/democratization; Human Consciousness; Teachers/educators; schoolboy/students/children/young; Risks/losses. The dialogues of the master's students with the author, through the letters, denoted the understanding of the central aspects of Pedagogy and Epistemology of Freire. The letters denote the most accentuated development of the critical conscience of the master students, through the analysis of the complex reality experienced by them and the understanding and application of the central categories of Freire's work, which allows concluding that the activity objectives have been achieved.

Keywords: Continuing Teacher Education. Science Teaching. Professional Master's Degree. Paulo Freire.

\section{Notas}

1 Estudo desenvolvido com apoio da Universidade Federal do Mato Grosso do Sul (UFMS).

2 Epígrafe colocada em uma das cartas escritas pelos mestrandos.

3 Houve uma abstenção. Não fecha 100\%, pois há professores atuando em mais de uma rede simultaneamente.

4 As frequências serão inseridas apenas como referências, já que a análise de conteúdo trabalhada neste artigo tem foco qualitativo.

5 Carvalho (2019) conceitua fakes news como os "[...] conteúdos intencionalmente e verificadamente produzidos com a intenção de enganar aqueles que leem, aqueles que assistem, aqueles que ouvem também”.

6 Os trechos das cartas, para facilitar a identificação, serão transcritos nesse artigo com destaques diferentes das citações, serão colocados em itálico, fonte 10 e com recuo de $1,5 \mathrm{~cm}$. 


\section{Referências}

ARRAIS, A. A. M.; BIZERRIL, M. X. A. A Educação Ambiental Crítica e o pensamento freireano: tecendo possibilidades de enfrentamento e resistência frente ao retrocesso estabelecido no contexto brasileiro. Rev. Eletrônica Mestr. Educ. Ambient., Rio Grande, v. 37, n. 1, p. 145-165, jan/abr. 2020. Disponível em: https://periodicos.furg.br/remea/article/view/10885. Acesso em: 20 abr. 2020.

AULER, D. Articulação Entre Pressupostos do Educador Paulo Freire e do Movimento CTS: Novos Caminhos Para a Educação em Ciências. Revista Contexto \& Educação, v. 22, n.77, p. 167-188, 2013. Disponível em: https://doi.org/10.21527/2179-1309.2007.77.167-188. Acesso em: 20 abr. 2020.

AULER, D.; DELIZOICOV, D. Educação CTS: articulação entre pressupostos do educador Paulo Freire e referenciais ligados ao movimento CTS. Las relaciones CTS em la educación cientifica, [S.l.: s.n], 2006. Disponível em: www.educadores.diaadia.pr.gov.br/arquivos/File/2010/ artigos_teses/Pedagogia2/aeducacao_cts.pdf. Acesso em: 20 abr. 2020.

CÊPEDA, V. A Nova Direita no Brasil: contexto e matrizes conceituais. Mediações, Londrina, v. 23 n. 2, p. 75-122, maio/ago. 2018. Disponível em: http:/www.uel.br/revistas/uel/index.php/ mediacoes/article/viewFile/34801/pdf. Acesso em: 26 abr. 2020.

CISLAGHI, J. F. Não é uma crise, é um projeto: a política de educação do governo Bolsonaro. In: CONGRESSO BRASILEIRO DE ASSISTENTES SOCIAIS, 6., Brasília, 2019. Anais... Brasília: [s.n.], 2019. Disponível em: https://www.ufjf.br/seminariointernacionalss/files/2019/09/anais_seminario2019.pdf. Acesso em: 26 abr. 2020.

FREIRE, Paulo. Conscientização: teoria e prática da libertação: uma introdução ao pensamento de Paulo Freire. Paulo Freire. Tradução de Kátia de Mello e silva. São Paulo: Cortez \& Moraes, 1979 .

FREIRE, P. Educação e Mudança. 8. ed. Rio de Janeiro: Paz e Terra, 1984.

FREIRE, P. Pedagogia do Oprimido. 18. ed. Rio de Janeiro: Paz e Terra, 1988.

FREIRE, P. Pedagogia da Autonomia. Saberes necessários à prática educativa. São Paulo: Paz e Terra, 1996.

FREIRE, P. Pedagogia da Indignação: cartas pedagógicas e outros escritos. São Paulo: Ed. UNESP, 2000.

GALIETA NASCIMENTO, T.; VON LINSINGEN, I. Articulações entre o enfoque CTS e a pedagogia de Paulo Freire como base para o ensino de ciências. Convergência, Toluca, v. 13, n. 42, p. 95-116, dic. 2006. Disponível em: http://www.scielo.org.mx/scielo.php?script=sci_arttext\&pid=S1405-14352006000300006\&lng=es\&nrm=iso. Acesso em: 26 abr. 2020.

HOBSBAWM, E. Tempos interessantes: uma vida no século XX. São Paulo: Companhia das Letras, 2002.

LEITE, A.P. M. A alfabetização midiática e informacional em tempos de fake news e o legado de Paulo Freire. In: PADILHA, P.R.; ABREU, J. (ORG.). Paulo Freire em tempos de fake news: artigos e projetos de intervenção produzidos durante o curso da EaD Freiriana do Instituto Paulo Freire. São Paulo : Instituto Paulo Freire, 2019. p. 12-18. Disponível em: https://www.eadfreiriana. org/curso-pftfn/. Acesso em: 26 abr. 2020. 
LEHER, Roberto. Apontamentos para análise da correlação de forças na educação brasileira: em prol da frente democrática. Educ.Soc., Campinas, v. 40, e0219831, 2019.Disponível em: https:// www.scielo.br/pdf/es/v40/1678-4626-es-40-e0219831.pdf . Acesso em: 26 abr. 2020.

LAYRARGUES, P P. A dimensão Freireana na Educação Ambiental. In: LOUREIRO, C F; TORRES, J R (orgs.). Educação Ambiental: dialogando com Paulo Freire. São Paulo: Cortez, 2014. Disponível em: https://www.mma.gov.br/estruturas/educamb/_arquivos/livro_ieab.pdf. Acesso em: 27 abr. 2020.

LORENZETTI, L. Estilos de pensamento em educação ambiental: uma análise a partir das dissertações e teses. Tese (Doutorado em Educação Científica e Tecnológica) - Universidade Federal de Santa Catarina, Florianópolis, 2008. Disponível em: https://repositorio.ufsc.br/ xmlui/handle/123456789/91657. Acesso em: 20 maio 2020.

MACEDO, R.G.M. Políticas educacionais e a questão do acesso ao ensino superior: notas sobre a deseducação. Cadernos de Campo, São Paulo, v.28, n.2, p. 26-31, 2019. Disponível em: http:// www.revistas.usp.br/cadernosdecampo/article/view/163922. Acesso em: 20 maio 2020.

MATO GROSSO DO SUL. Lei complementar nº 266, de 10 de julho de 2019. Altera, acrescenta e revoga dispositivos à Lei Complementar n⿳o 87, de 31 de janeiro de 2000, que dispõe sobre o Estatuto dos Profissionais da Educação Básica do Estado de Mato Grosso do Sul e dá outras providências. Diário Oficial Eletrônico do Estado de Mato Grosso do Sul, Campo Grande, MS, n. 9.941, 12 jul. 2019. P. 2-7. Disponível em: http://www.acpms.com.br/lei-complementar-no-266de-10-de-julho-de-2019-do-estado-de-ms-de-12-07-2019-pags-2-a-7/. Acesso em: 20 maio 2020.

NACIF, P.G.S.; SILVA FILHO, P. A educação brasileira na mira do obscurantismo e Estado mínimo. In: BRASIL: incertezas e indefinições. São Paulo: Fundação Perseu Abramo, 2019. p. 231249. Disponível em: https://fpabramo.org.br/publicacoes/estante/brasil-incertezas-e-submissao/. Acesso em: 20 jun. 2020.

PRIOLLI, G. A era da pós-verdade. Carta Capital, São Paulo, 13 jan. 2017. Disponível em: https://www.sindsep-pe.com.br/artigos-detalhe/a-era-da-p-s-verdade/4514\#.XqdB9W5FxlY. Acesso em: 10 abr. 2020.

REIS, L. C. R. dos. Militarização de Escolas Públicas e o Governo Bolsonaro. Tecnia, v.4, n. 2, 2019. Disponível em: http://revistas.ifg.edu.br/tecnia/article/view/744. Acesso em: 10 abr. 2020.

RICARDO, E. C. A problematização e a contextualização no ensino das ciências: acerca das idéias de Paulo Freire e Gérard Fourez. In: ENCONTRO NACIONAL DE PESQUISA EM EDUCAÇÃO EM CIÊNCIAS, 4., Bauru, SP. Atas... Bauru: ABRAPEC, 2003. Disponível em: http://abrapecnet. org.br/atas_enpec/ivenpec/Arquivos/Orais/ORAL019.pdf. Acesso em: 26 abr. 2020.

SANTOS, W. L. P. dos. Contextualização no ensino de ciências por meio de temas CTS em uma perspectiva crítica. Ciência \& Ensino, v. 1, número especial, nov. 2007. Disponível em: http:// files.gpecea-usp.webnode.com.br/200000358-0e00c0e7d9/AULA\%206-\%20TEXTO\%2014-\%20 CONTEXTUALIZACAO\%20NO\%20ENSINO\%20DE\%20CIENCIAS\%20POR\%20MEI.pdf. Acesso em: 20 jun. 2020.

SANTOS, C; PEREIRA, R. Militarização e Escola Sem Partido: duas faces de um mesmo projeto. Revista Retratos da Escola, Brasília, v.12, n.23, p.255- 270, jul./out. 2018. Disponível em: http://www.feeba.uneb.br/wp-content/uploads/2018/11/Militariza\%C3\%A7\%C3\%A3o-e-Escola-Sem-Partido_-duas-faces-de-um-mesmo-projeto-1.pdf. Acesso em: 10 abr. 2020.

SEVERO, R.G. Gaudêncio Frigotto: um diálogo sobre o contexto político e educacional brasileiro. Entrevistado: Gaudêncio Frigotto. Conjectura: Filos. Educ., Caxias do Sul, RS, Ahead of Print, v. 24, e019021, 2019. Disponível em: http://www.ucs.br/etc/revistas/index.php/conjectura/ article/view/7561. Acesso em: 20 abr. 2020. 
SOUZA, C. Aplicabilidade do círculo de cultura em contextos de pós-verdade. In: PADILHA, P.R.; ABREU, J. (ORG.). Paulo Freire em tempos de fake news: artigos e projetos de intervenção produzidos durante o curso da EaD Freiriana do Instituto Paulo Freire. São Paulo: Instituto Paulo Freire, 2019. p. 54-60. Disponível em: https://www.paulofreire.org/download/eadfreiriana/ Saiba_Mais_Curso_PFTFN.pdf. Acesso em: 20 abr. 2020.

TAFFAREL, C.N.Z.; NEVES, M.L.C. Tendências da educação frente à correlação de forças na luta de classes: uma análise do governo Bolsonaro na perspectiva educacional. Estudos IAT, Salvador, v.4, n.2, p. 310-329, set., 2019. Disponível em: http://estudosiat.sec.ba.gov.br/index. php/estudosiat/article/view/153. Acesso em: 20 maio 2020.

ZAUITH, G.; HAYASHI, M. C. P. I. A influência de Paulo Freire no ensino de ciências e na educação CTS: uma análise bibliométrica. Revista HISTEDBR On-Line, v. 13, n.49, p. 267-293, 2013. Disponível em: https://doi.org/10.20396/rho.v13i49.8640332. Acesso em: 20 abr. 2020. 